\title{
KEPAILITAN BUMN YANG DIMOHONKAN ATAS DASAR HAK - HAK BURUH YANG TIDAK DIPENUHI
}

\author{
Ardini Octaviarini \\ ardiniocta@yahoo.com
}

Universitas Airlangga

\begin{abstract}
BUMN are private corporate entities so that the laws governing Manpower are applicable to Law 13 of 2003. Therefore, the normative rights set forth in Law No. 13 of 2003 must be met by companies for their workers. These normative rights are, among others, when the Bankrupt Company, ie, a one time severance pay under the provisions of Article 156 Paragraph 2, severance pay for a one-time stipulation of Article 156 paragraph 3 and compensation pay pursuant to paragraph 156 4. Where there is labor rights is not fulfilled by a state-owned enterprise, workers may file for bankruptcy in the company, in its qualification as a Preferen creditor. Based on the research, the stateowned enterprises should be clearly stated in a company to protect the company's existing components in case of Bankruptcy, if the State participates, there must be at least $51 \%$ of the shares therein, so that the control, regulation and controlling functions performed the government is clear that the company's goals are achieved. It is necessary to have the same meaning / meaning as the state-owned enterprise which is engaged in public interest. Because of Article 2 paragraph 5 of Law No. 37 of 2004 with the explanation is not in line. Article 2 paragraph 5 of the Law on Bankruptcy refers to state-owned enterprises in the field of public interest, while in the explanation states that stateowned all state-owned capital and not divided into shares. Between the contents of the article and the explanation is not synchronized, then the provisions should be mentioned directly Perum, in order to achieve legal certainty.
\end{abstract}

Keywords : BUMN, Bankrupt, employment

\begin{abstract}
Abstrak
BUMN merupakan entitas perusahaan privat sehingga hukum yang mengatur tentang Ketenagakerjaan berlaku UU No 13 Tahun 2003. Oleh karena itu, hak-hak normatif yang diatur dalam UU No 13 Tahun 2003 harus dipenuhi perusahaan untuk pekerjanya. Hak-hak normatif tersebut antara lain ketika perusahaan Pailit, yakni uang pesangon satu kali ketentuan Pasal 156 Ayat 2, uang pesangon masa kerja sebesar satu kali ketentuan Pasal 156 ayat 3 dan uang penggantian hak sesuai Pasal 156 ayat 4. Apabila ada hak-hak buruh yang tidak dipenuhi perusahaan BUMN, maka buruh dapat mengajukan pailit pada perusahaan tersebut, dalam kualifikasinya sebagai kreditur Preferen. Berdasarkan penelitian tersebut, seharusnya status BUMN harus dipaparkan secara jelas dalam suatu perusahaan hal ini untuk memproteksi komponen perusahaan yang ada didalamnya apabila terjadi Kepailitan, jika Negara ikut andil maka harus pula terdapat minimal $51 \%$ saham didalamnya, sehingga fungsi pengendalian, pengaturan dan kontrolling yang dilakukan pemerintahpun jelas agar tujuan perusahaan tersebut tercapai. Perlu adanya pengertian/makna yang sama mengenai BUMN yang bergerak dalam bidang kepentingan publik. Karena antara Pasal 2 ayat 5 UU No 37 Tahun 2004 dengan penjelasannya tidak sejalan. Pasal 2 ayat 5 UU Kepailitan menyebut tentang BUMN di bidang kepentingan publik, sementara pada penjelasan menyatakan BUMN yang seluruh modalnya dimiliki Negara dan tidak terbagi atas saham. Antara isi pasal dan penjelasan tidak singkron, maka seharusnya ketentuan tersebut menyebut langsung Perum, agar tercapainya kepastian hukum.
\end{abstract}

Kata Kunci : $B U M N$, kepailitan, ketenagakerjaan 


\section{A. PENDAHULUAN}

\section{Latar Belakang}

Ketenagakerjaan merupakan unsur yang tidak terlepaskan dari pembangunan Nasional berdasarkan Pancasila dan Undang Undang Dasar Negara Republik Indonesia Tahun 1945. Tenaga kerja mempunyai peranan dan kedudukan yang sangat penting sebagai pelaku dan sasaran pembangunan Nasional. Oleh karena itu harus ada hak-hak tenaga kerja yang diatur dalam peraturan Indonesia demi keadilan dan kepastian hukum, yang di dalamnya termasuk perlindungan atas hak-hak pekerja. Di dalam perjalanannya, perusahaan tidak selamanya mengalami pertumbuhan yang stabil dan bahkan sebuah perusahaan dapat mengalami kebangkrutan atau kepailitan. Pailit merupakan suatu keadaan dimana debitur tidak mampu lagi untuk melakukan pembayaran-pembayaran terhadap utang-utang dari para krediturnya.

Kepailitan berdasarkan Pasal 1 angka 1 Undang Undang Nomor 37 Tahun 2004 Tentang Kepailitan dan Penundaan Kewajiban Pembayaran Utang (selanjutnya disebut UUK) adalah sita umum atas kekayaan debitor pailit yang pengurusan dan pemberesannya dilakukan oleh kurator di bawah pengawasan hakim pengawas. Keadaan tidak mampu membayar lazimnya disebabkan karena kesulitan kondisi keuangan (financial distress) dari usaha debitor yang telah mengalami kemunduran. Kepailitan merupakan suatu jalan keluar yang bersifat komersial untuk keluar dari persoalan utang piutang yang menghimpit seorang debitur karena sudah tidak mampu lagi membayar utang piutang tersebut. ${ }^{1}$

Pada dasarnya UUK tidak membedakan kepailitan. Berdasarkan UUK debitur yang dapat dipailitkan menjadi dua, yaitu orang perorangan (pribadi) dan badan hukum. Artinya, baik perorangan maupun badan hukum dapat dipailitkan. ${ }^{2}$ Salah satu pembaharuan dalam UUK ialah menambah pihak-pihak yang dapat mengajukan kepailitan terhadap instansi tertentu, salah satunya ialah permohonan pailit terhadap BUMN. Pasal 2 ayat (5) UUK

\footnotetext{
${ }^{1}$ M. Hadi Subhan, Hukum Kepailitan : Prinsip, Norma dan Praktik di Peradilan, Kencana, Jakarta, 2007, hlm 2.

${ }^{2}$ Adrian Sutedi, Hukum Kepailitan, Ghalia Indonesia, Bogor, 2009, hlm. 147
} 
menyatakan bahwa dalam hal Debitor adalah Badan Usaha Milik Negara yang bergerak di bidang kepentingan publik, maka permohonan pernyataan pailit hanya dapat diajukan oleh Menteri Keuangan. BUMN yang dimaksud hanyalah BUMN yang bergerak di bidang kepentingan publik saja.

Berdasarkan penjelasan Pasal 2 ayat (5) UUK, yang dimaksud dengan BUMN yang bergerak di bidang kepentingan pubik ialah: "badan usaha milik negara yang seluruh modalnya dimiliki Negara dan tidak terbagi atas saham". Artinya untuk bisa disebut sebagai BUMN yang bergerak di bidang kepentingan publik haruslah memenuhi dua syarat tersebut. UUK tidak memberikan penjelasan tentang itu. Di samping itu, penjelasan tersebut juga mengandung kelemahan. Kelemahan yang dimaksud adalah bila disingkronkan dengan Undang-Undang Nomor 19 Tahun 2003 Tentang BUMN (Selanjutnya disebut UU BUMN). Pengertian BUMN yang bergerak di bidang kepentingan publik hampir sama dengan pengertian Perusahaan Umum (Perum). Hal ini dapat dilihat dalam Pasal 1 angka 4 UU BUMN. Menurut Pasal 1 angka 4 UU BUMN, Perum adalah BUMN yang seluruh modalnya dimiliki negara dan tidak terbagi atas saham, yang bertujuan untuk kemanfaatan umum berupa penyediaan barang dan/atau jasa yang bermutu tinggi dan sekaligus mengejar keuntungan berdasarkan prinsip pengelolaan perusahaan. BUMN yang seluruh atau sebagian besar modalnya berasal dari kekayaan negara yang dipisahkan merupakan salah satu pelaku ekonomi dalam sistem perekonomian nasional, di samping usaha swasta dan koperasi.

Kasus paling besar ialah dipailitkannya suatu BUMN yaitu PT Dirgantara Indonesia (DI) karena dalam sejarah ini baru pertama kali BUMN dipailitkan. ${ }^{3}$ Namun akhirnya batal pailit setelah Mahkamah Agung menolak permohonan pailit mantan karyawan DI. Permohonannya sendiri diajukan mantan karyawan terkait kekurangan pembayaran iuran pensiun setelah mereka di PHK. Mahkamah Agung berkesimpulan bahwa BUMN, baik berbentuk Perusahaan Umum (Perum) atau Persero hanya dapat dimohonkan pailit oleh Menteri Keuangan (Menkeu). BUMN yang seluruh modalnya dimiliki oleh negara, yang

\footnotetext{
${ }^{3}$ Usman Rachmadi, Dimensi Hukum Kepailitan di Indonesia, Gramedia Pustaka Utama, Jakarta, 2004, hlm
} 
melaksanakan kegiatan kepentingan publik hanya dapat dimohonkan pailit oleh Menteri Keuangan.

Di Indonesia, berkaitan dengan permasalahan pemenuhan hak-hak buruh tersebut sebenarnya telah diatur dengan jelas dalam serangkaian peraturan perundang undangan. Dalam Undang Undang Nomor 13 Tahun 2003 Tentang Ketenagakerjaan (selanjutnya disebut UU Ketenagakerjaan ) Pasal 95 ayat (4) disebutkan bahwa "Dalam hal perusahaan dinyatakan pailit atau dilikuidasi berdasarkan peraturan perundang - undangan yang berlaku, maka upah dan hak - hak lainnya dari pekerja/buruh merupakan utang yang didahulukan pembayarannya." Dalam UUK Pasal 39 disebutkan bahwa (1) Pekerja yang bekerja pada Debitor dapat memutuskan hubungan kerja, dan sebaliknya Kurator dapat memberhentikannya dengan mengindahkan jangka waktu menurut persetujuan atau ketentuan perundang undangan yang berlaku dengan pengertian bahwa hubungan kerja tersebut dapat diputuskan dengan pemberitahuan paling singkat 45 (empat puluh lima) hari sebelumnya; dan (2) Sejak tanggal putusan pernyataan pailit diucapkan, upah yang terutang sebelum maupun sesudah putusan pernyataan pailit diucapkan merupakan utang harta pailit.

Melihat ke UU Ketenagakerjaan, Pasal 1 angka 3 memberikan pengertian Pekerja adalah setiap orang yang bekerja dengan menerima imbalan dalam bentuk apapun. Pengertian ini agak umum namun maknanya lebih luas karena dapat mencakup semua orang yang bekerja pada siapa saja baik perorangan, persekutuan, badan hukum dan badan lainnya dengan menerima upah selama ini diidentikkan dengan uang, padahal ada pula pekerja/buruh yang menerima imbalan dalam bentuk barang. ${ }^{4}$ Sebagaimana dengan istilah pemberi kerja/pengusaha dalam hal ini perusahaan, berdasarkan UU Ketenagakerjaan adalah setiap bentuk usaha yang berbadan hukum atau tidak, milik orang perseorangan, milik persekutuan, atau milik badan hukum, baik milik swasta maupun milik negara yang mempekerjakan pekerja/buruh dengan membayar upah atau imbalan dalam bentuk lain atau usaha usaha sosial dan usaha usaha lain yang mempunyai pengurus dan mempekerjakan orang lain dengan membayar upah atau imbalan dalam bentuk lain. Mengenai hubungan kerja yang telah ada 2006, hlm 35

${ }^{4}$ Lalu Husni, Pengantar Hukum Ketenagakerjaan Indonesia, Ed. Revisi, Raja Grafindo Persada, Jakarta, 
antara perusahaan dan pekerja, maka dengan sendirinya akan terputus dengan adanya putusan pengadilan.

Hal ini berdasarkan Pasal 21 ayat 1 Undang Undang Nomor 25 Tahun 1997 yang menyatakan bahwa Perjanjian kerja berakhir apabila :

a. Meninggal dunia;

b. Berakhirnya jangka waktu perjanjian kerja;

c. Adanya putusan pengadilan yang mempunyai kekuatan hukum tetap;

d. Adanya kejadian atau keadaan yang dicantumkan dalam perjanjian kerja yang dapat menyebabkan berakhirnya perjanjian hubungan kerja; dan

e. Keadaan memaksa.

Selama ini masyarakat cenderung menilai bahwa kepailitan merupakan suatu cacat hukum dan kenestapaan suatu perusahaan terhadap hak-hak para kreditur yang berkaitan dengan perusahaan tersebut, khususnya para tenaga kerja, karena kurang memahaminya tenaga kerja terhadap hukum kepailitan. Memang, disatu sisi terdapat UU Ketenagakerjaan yaitu yang mengatur hak buruh pada perusahaan pailit. Namun, ada pula UUK, dengan demikian, terdapat benturan antara pemenuhan hak buruh yang didahulukan berdasar UU Ketenagakerjaan dan UU Kepailitan. Tetapi dalam hukum, terdapat asas Lex Specialis derogat legi generalis yaitu peraturan yang lebih khusus mengalahkan peraturan umum, sehingga hak buruh pada saat pailit hanya mengacu pada peraturan yang lebih khusus yaitu UU Kepailitan. Selain itu, dalam Peraturan Pemerintah Nomor 8 Tahun 1981 tentang Perlindungan Upah, Pasal 27 disebutkan bahwa "dalam hal pengusaha dinyatakan pailit, maka upah buruh merupakan hutang yang didahulukan pembayarannya sesuai dengan peraturan perundang undangan tentang kepailitan yang berlaku”.

Dalam Pasal 26 UU UUK kurator memang mempunyai kewenangan untuk melakukan pengajuan tuntutan dan kewajiban yang menyangkut harta pailit. Apalagi jika, masih ada kreditur-kreditur lain yang harus dipenuhi juga haknya. Dengan demikian, dapat dilihat bahwa kewajiban yang harus dilaksanakan oleh perusahaan yang pailit sebagai debitur, tidak hanya berkaitan dengan kreditur, tetapi juga kewajiban pemenuhan upah kepada pekerja. Posisi seperti ini merupakan salah satu alasan mengapa sampai terjadi demonstrasi oleh buruh 
dalam perusahaan pailit. Dalam hal ini putusan kepilitan suatu perusahaan biasanya diikuti oleh putusan status pekerjanya, yaitu terjadi pemutusan hubungan kerja.

Dalam praktiknya manakala terjadi permasalahan pailit dan terjadi pemutusan hubungan kerja dalam satu perusahaan, seringkali pekerja kesulitan memperoleh informasi dan hak-hak mereka. Seringkali terjadi perselisihan Pekerja dengan Pihak Perusahaan yang diwakili oleh Kurator. Pasal 151 ayat (1) UU Ketenagakerjaan menyebutkan bahwa pengusaha, pekerja/buruh, serikat pekerja/serikat buruh, dan pemerintah, dengan segala upaya harus mengusahakan agar jangan terjadi pemutusan hubungan kerja. Setelah instansi yang bertanggung jawab di bidang ketenagakerjaan setempat menerima pencatatan perselisihan, instansi tersebut wajib menawarkan kepada para pihak untuk menyepakati memilih penyelesaian melalui konsiliasi atau melalui arbitrase. Jika para pihak tidak memilih penyelesaian melalui konsiliasi dan arbitrase maka penyelesaian perselisihan dilakukan dengan mediator.

Berdasarkan uraian diatas, maka pemenuhan kebutuhan akan sistem pengupahan pekerja yang layak merupakan suatu orientasi hak atas setiap warga negara atas pekerjaan dan penghidupan yang layak bagi kemanusiaan dan dapat disimpulkan pula bahwa dalam praktik peradilan di Indonesia masih sering terjadi pertentangan dalam menyelesaikan masalah ketika perusahaan pailit dengan para pekerja. Dengan adanya kreditur-kreditur pemegang jaminan, sering kali para pekerja khawatir perusahaan pailit tersebut tidak melakukan pemenuhan pembayaran upah dan pesangon karena harta perusahaan sebagai debitur sudah habis atau telah berkurang untuk membayar para kreditur pemegang hak jaminan. Dalam jurnal ini ada dua permasalahan hukum yakni apakah pekerja / buruh pada perusahaan BUMN berlaku UU No 13 Tahun 2003 tentang Ketenagakerjaan dan apakah hak-hak buruh yang tidak terpenuhi oleh Perusahaan dapat mengajukan pailit terhadap BUMN tersebut.

\section{Tujuan Penelitian}

Penelitian ini bertujuan untuk menganalisis tentang kepailitan BUMN yang dimohonkan atas dasar hak-hak buruh yang tidak dipenuhi, dengan titik pembahasan pada apakah UU No 13 Tahun 2003 tentang Ketenagakerjaan berlaku pada pekerja / buruh pada 
perusahaan BUMN dan apakah hak-hak buruh yang tidak terpenuhi oleh Perusahaan dapat mengajukan pailit terhadap BUMN tersebut.

\section{Manfaat Penelitian}

Dari segi teoritik penelitian ini diharapkan berguna bagi pengembangan hukum Bisnis/ketenagakerjaan. Dari segi praktis penelitian ini diharapkan dapat berguna bagi praktik hukum dan penegakan hukum mengenai penanganan kasus atau permasalahan-permasalahan hukum yang berkaitan dengan ketenagakerjaan di BUMN.

\section{Metode Penelitian}

Penelitian ini merupakan penelitian hukum normatif, bertujuan mencari pemecahan atas isu hukum yang timbul didalamnya, sehingga hasil yang dicapai adalah memberikan preskripsi mengenai apa yang seyogyanya atas isu hukum yang diajukan. Pendekatan yang digunakan adalah pendekatan perundang-undangan (statute approach), pendekatan konseptual (conceptual approach), dan pendekatan kasus (case approach). ${ }^{5}$ Metode analisis bahan hukum didasarkan pada bahan hukum primer berupa perundangan-undangan dikumpulkan dengan metode inventarisasi dan kategorisasi.

\section{B. PEMBAHASAN}

\section{Cakupan Hubungan Kerja dalam UU Ketenagakerjaan}

Semua orang yang bekerja disektor swasta baik pada perorangan maupun badan hukum disebut sebagai buruh. Hal ini ditegaskan dalam Pasal 1 ayat 1 a Undang Undang 22 Tahun 1957 tentang Penyelesaian Perselisihan Perburuhan. Dalam pasal ini buruh diartikan sebagai barang siapa yang bekerja pada majikan dengan menerima upah. Setelah lahirnya Undang Undang 13 Tahun 2003 tentang Ketenagakerjaan istilah Buruh disandingkan dengan istilah Pekerja. Istilah Buruh dan Pekerja secara yuridis sebenarnya adalah sama dan tidak ada perbedaan diantara keduanya. Pekerja adalah aset perusahaan yang begitu penting, karena

\footnotetext{
${ }^{5}$ Peter Mahmud Marzuki, Penelitian Hukum, Kencana Prenada Media Group, Jakarta, 2005, hlm. 113
} 
keberhasilan suatu perusahaan sangat tergantung dari pekerjanya. Dalam hubungan antara perusahaan dan pekerja tersebut terjadi perikatan kerja yang membentuk hubungan hukum, yakni suatu perjanjian kerja. Suatu perjanjian kerja, dapat berupa perjanjian tertulis maupun lisan yang mengikuti syarat-syarat perjanjian, sebagaimana diatur dalam Pasal 1320 KUHPerdata. Adanya perjanjian kerja, yakni upah yang memadai dan jaminan sosial tenaga kerja adalah hak-hak pekerja yang dijamin oleh Undang-Undang.

Menurut Bahder Johan Nasution "Tujuan yang hendak dicapai dalam hubungan industrial adalah mewujudkan masyarakat adil dan makmur dengan cara menciptakan ketenagaan bekerja dan berusaha yang dilandasi dengan prinsip kemitraan dan keseimbangan, berasaskan kekeluargaan dan gotong royong serta musyawarah untuk mufakat". 6

Pemutusan hubungan kerja (PHK) adalah pengakhiran hubungan kerja karena suatu hal tertentu yang mengakibatkan berakhirnya hak- hak dan kewajiban (prestasi dan kontra prestasi) antara pekerja buruh dengan pengusaha (Pasal 1 angka 25 Undang Undang Ketenagakerjaan). Salah satu pasal dalam UUD NRI 1945 yaitu Pasal 28D yang menentukan bahwa setiap orang berhak untuk mendapatkan imbalan dan perlakuan yang adil dan layak dalam hubungan kerja.

Entitas BUMN dapat ditelusuri dari konsep hukum perusahaan pada umumnya. Istilah "perusahaan" pada awalnya tidak terdapat dalam Kitab Undang-Undang Hukum Dagang (KUHD) Stb.1847-23, dan dikenal pada waktu itu adalah istilah pedagang sebagaimana diatur dalam Pasal 2 sampai dengan Pasal 5 KUHD. Dalam perkembangannya, terjadi perubahan KUHD pada tahun 1938 dengan Stb. 1938-276 istilah pedagang diganti dengan perusahaan. ${ }^{7}$ Namun mengenai pengertian perusahaan ternyata dalam KUHD sendiri tidak memberikan pengertiannya. Berdasarkan Pasal 1 butir b Undang Undang Nomor 3 Tahun 1982 tentang Wajib Daftar Perusahaan, yang menentukan: "Perusahaan adalah setiap bentuk usaha yang menjalankan setiap jenis usaha yang bersifat tetap dan terus-menerus dan

\footnotetext{
${ }^{6}$ Bahder Johan Nasution, Hukum Ketenagakerjaan, Kebebasan Berserikat bagi Pekerja, Mandar Maju, Bandung, 2004, hlm 165

7 H.M.N. Purwosuttjipto, Pengertian Pokok Hukum Dagang Indonesia 1, Pengertian Dasar Hukum Dagang, Djambatan, Jakarta, 1995, hlm 10
} 
yang didirikan, bekerja serta berkedudukan dalam wilayah negara Republik Indonesia, untuk tujuan memperoleh keuntungan dan atau laba".Begitu pula pada Pasal 1 butir 1 UndangUndang Nomor 8 Tahun 1997 tentang Dokumen Perusahaan, yang menentukan: "Perusahaan adalah setiap bentuk usaha yang melakukan kegiatan secara tetap dan terus-menerus dengan tujuan memperoleh keuntungan atau laba, baik yang diselenggarakan oleh orang perorangan maupun badan usaha yang berbentuk badan hukum/bukan badan hukum, yang didirikan dan berkedudukan di wilayah RI.

Landasan Konstitusional BUMN adalah Pasal 33 ayat 3 dan ayat 3 UUD 1945, yang menyatakan bahwa "semua cabang produksi yang menguasai hajat hidup orang banyak dikuasai oleh negara dan digunakan sebesar besarnya untuk kemakmuran rakyatnya “. BUMN ikut berperan dalam sistem perekonomian nasional antara lain menghasilkan barang dan/atau jasa yang diperlukan dalam rangka mewujudkan sebesar-besarnya kemakmuran masyarakat. Peran BUMN dirasakan semakin penting sebagai pelopor dan/atau perintis dalam sektorsektor usaha yang belum diminati usaha swasta. Memperhatikan sifat usaha BUMN, yaitu untuk memupuk keuntungan dan melaksanakan kemanfaatanm umum, dalam Undang Undang Nomor 19 Tahun 2003 Tentang Badan Usaha Milik Negara, BUMN disederhanakan menjadi dua bentuk yaitu Perusahaan Perseroan (Persero) dan Perusahaan Umum (Perum).

Persero adalah BUMN yang tujuannya mengejar keuntungan, dan modalnya terbagi atas saham yang paling sedikit 51\% dari saham yang dimiliki oleh negara dan ditundukkan kepada ketentuan tentang Perseroan Terbatas, sedangkan Perum adalah BUMN yang tidak terbagi atas saham. ${ }^{8}$ Rumusan Perseroan berasal dari kata sero, yang berarti saham. Menurut ketentuan Pasal 1 angka 1 Undang-Undang Nomor 40 tahun 2007 tentang Perseroan Terbatas menentukan : "Perseroan Terbatas, yang selanjutnya disebut Perseroan adalah badan hukum yang merupakan persekutuan modal, didirikan berdasarkan perjanjian, melakukan kegiatan usaha dengan modal dasar yang seluruhnya terbagi dalam saham, dan memenuhi persyaratan yang ditetapkan dalam undang-undang serta peraturan pelaksananya".

\footnotetext{
${ }^{8}$ Rudhi Prasetya. Perseroan Terbatas Teori dan Praktik. Jakarta : Sinar Grafika, 2011, h. 8
} 
Perusahaan Perseroan, merupakan BUMN yang berbentuk perseroan terbatas yang modalnya terbagi dalam saham yang seluruh atau paling sedikit 51\% (lima puluh satu persen) sahamnya dimiliki oleh Negara Republik Indonesia yang tujuan utamanya mengejar keuntungan. Hal inilah yang membedakannya dengan bentuk BUMN lainnya, yaitu Perusahaan Umum (Perum). Perusahaan Umum, merupakan BUMN yang seluruh modalnya dimiliki Negara dan tidak terbagi atas saham, yang bertujuan untuk kemanfataan umum berupa penyediaan barang dan/atau jasa yang bermutu tinggi dan sekaligus mengejar keuntungan berdasarkan prinsip pengelolaan perusahaan (Pasal 1 angka 4 Undang-Undang BUMN).

\section{a. UU Ketenagakerjaan Berlaku Pada Perusahaan BUMN}

Hukum Ketenagakerjaan dapat bersifat perdata dan dapat bersifat publik. Dikatakan sifat perdata oleh karena sebagaimana kita ketahui bahwa perdata mengatur kepentingan orang perorangan dalam hal antara tenaga kerja dan pengusaha yaitu dimana mereka mengadakan suatu perjanjian yang disebut dengan perjanjian kerja. Sedangkan mengenai hukum perjanjian diatur dalam KUHPerdata Buku III disamping bersifat perdata juga bersifat publik alasannya adalah:

1) Dalam hal-hal tertentu Negara / Pemerintah turut campur tangan dalam masalah masalah ketenagakerjaan, misalnya Pemutusan Hubungan Kerja;

2) Adanya sanksi-sanksi / aturan didalam setiap undang undang atau peraturan perundang undangan di bidang ketenagakerjaan. ${ }^{9}$

Keikutsertaan pemerintah dalam kepemilikan saham terdapat dalam Pasal 1 Peraturan Pemerintah Nomor 52 Tahun 2002 Tentang Penyertaan Modal Negara Republik Indonesia ke Dalam Modal Saham, menyebutkan bahwa "Negara Republik Indonesia melakukan penyertaan modal ke dalam modal saham PT Dirgantara Indonesia, PT PAL Indonesia, PT Pindad, PT Dahana, PT Krakatau Steel, PT Barata Indonesia, PT Boma Bisma Indra, PT Industri Kereta Api, PT Industri Telekomunikasi Indonesia dan PT LEN Industri”.

\footnotetext{
${ }^{9}$ Sendjun W. Manullang, Pokok - Pokok Hukum Ketenagakerjaan di Indonesia, Rineka Cipta, Jakarta,
} 1998, hlm 1 
PT. Dirgantara Indonesia merupakan salah satu BUMN yang bergerak dalam bidang kedirgantaraan. Sebagai suatu Badan Usaha Milik Negara, PT. Dirgantara Indonesia memiliki karakteristik bentuk sebagai Perusahaan Perseroan (Persero). PT. Dirgantara Indonesia sebagai salah satu wahana transformasi industri untuk menjadi pusat keunggulan di bidang industri dirgantara yang berorientasi bisnis dan mampu mendukung kepentingan nasional. ${ }^{10}$

Kewenangan pengajukan permohonan pailit suatu Badan Usaha Milik Negara (BUMN) adalah Menteri Keuangan. Terhadap PT. Dirgantara Indonesia yang merupakan salah satu Badan Usaha Milik Negara, Majelis Hakim Pengadilan Niaga berpendapat bahwa PT. Dirgantara Indonesia bukan BUMN yang sahamnya seratus persen dikuasai Negara. Oleh karena itu, Menteri Keuangan bukan satu-satunya pihak yang dapat menggugat pailit PT. Dirgantara Indonesia.

\section{b. Pihak yang Memohonkan Pailit}

Menurut J. Djohansjah, dalam tulisannya yang berjudul "Pengadilan Niaga", pengertian Kepailitan merupakan suatu proses dimana: ${ }^{11}$

1) Seorang Debitor yang mempunyai kesulitan keuangan untuk membayar utangnya dinyatakan pailit oleh Pengadilan, dalam hal ini Pengadilan Niaga, dikarenakan Debitur tersebut tidak dapat membayar utangnya.

2) Harta Debitur dapat dibagikan kepada para Kreditor sesuai dengan peraturan Kepailitan.

Kreditor adalah orang yang mempunyai piutang karena perjanjian atau UndangUndang yang dapat ditagih di muka pengadilan, baik kreditor konkuren, kreditor separatis (pemegang hak jaminan), maupun kreditor preferen. Debitor adalah orang yang mempunyai utang karena perjanjian atau Undang-Undang yang pelunasannya dapat ditagih dimuka pengadilan. Utang adalah kewajiban yang dinyatakan atau dapat dinyatakan dalam jumlah

${ }^{10}$ http://www.kompas.com., PT Dirgantara Indonesia Batal Pailit. Rabu, 24 Oktober 2007, diakses pada 2 September 2014

${ }^{11}$ Rudhy A. Lontoh, Denny Kailimang, dan Benny Ponto, [Eds.], Penyelesaian Utang-Piutang: Melalui Pailit atau Penundaan Kewajiban Pembayaran Utang, Alumni, Bandung, 2001, hlm 23 
uang baik dalam mata uang Indonesia maupun mata uang asing, baik secara langsung maupun yang akan timbul di kemudian hari atau kontinjen, yang timbul karena perjanjian atau undangundang dan yang wajib dipenuhi oleh Debitor dan bila tidak dipenuhi memberi hak kepada Kreditor untuk mendapat pemenuhannya dari harta kekayaan Debitor.

Keberadaan ketentuan tentang kepailitan baik sebagai suatu lembaga atau sebagai suatu upaya hukum khusus merupakan suatu ringkasan konsep atas asas dalam Pasal 1131 dan 1132 KUH Perdata yakni adanya kepastian pembayaran atas transaksi yang telah diadakan oleh debitur terhadap krediturnya, dengan kedudukan yang proporsioal.

Sesuai ketentuan Pasal 1132 KUH Perdata, bahwa salah satu pengecualian yang diberikan oleh perundang-undangan atas asas paritas creditorium adalah terhadap kreditur separatis dan preferen, yakni kreditur yang mempunyai kedudukan terpisah dalam boedel pailit. Berdasarkan Pasal 1133 KUH Perdata, pengecualian tersebut dari hak istimewa (privilege), gadai dan hipotik. Dalam Pasal 1134 KUH Perdata lebih lanjut dimuat bahwa ketentuan Gadai dan Hipotik mempunyai kedudukan lebih tinggi untuk didahulukan daripada Hak Istimewa, kecuali dalam hal-hal dimana oleh undang undang ditentukan sebaliknya.

Berkaitan dengan itu pula, syarat-syarat dikabulkannya permohonan kepailitan menjadi sangat penting, yakni: Pailit ditetapkan apabila debitur yang mempunyai 2 kreditur atau lebih tidak mampu membayar sedikitnya satu utang yang jatuh tempo (Pasal 2 ayat 1 UUK). Selain itu keterkaitan pengertian utang juga terdapat pada Pasal 1 angka 6 UUK:

“ Utang adalah kewajiban yang dinyatakan atau dapat dinyatakan dalam jumlah uang baik dalam mata uang Indonesia maupun mata uang asing, baik secara langsung maupun akan timbul dikemudian hari, atau kontinjen, yang timbul karena perjanjian atau undang - undang dan yang wajib dipenuhi oleh Debitur dan bila tidak dipenuhi memberi hak kepada Kreditur untuk mendapat pemenuhannya dari harta kekayaan Debitur “.

Timbulnya penafsiran utang yang berbeda antara para hakim tidak terlepas dari Penjelasan Pasal 1 ayat 1 UUK yang menyebutkan: utang yang tidak dibayar oleh dibitor sebagaimana dimaksud dalam ketentuan ini adalah utang pokok atau bunga. Pengertian 
tersebut secara harfiah ditafsirkan sebagai utang dari perbuatan hukum yang dapat dinyatakan pailit adalah: ${ }^{12}$

1. Orang perorangan;

2. Perserikatan-perserikatan dan perkumpulan-perkumpulan tidak berbadan hukum lainnya;

3. Perseroan-perseroan, perkumpulan-perkumpulan, koperasi maupun yayasan yang berbadan hukum;

4. Harta peninggalan.

Jadi dapat disimpulkan bahwa yang dibutuhkan untuk dapat dinyatakan pailit adalah kapasitas dan kecakapan suatu subyek hukum untuk melakukan tindakan-tindakan keperdataan, dan bukan hal lainnya.

\section{Permohonan Pailit pada BUMN}

Kepailitan Debitur akan membawa akibat hukum tidak hanya pada kreditur dan harta bendanya, tetapi juga pada buruh atau tenaga kerja. Dengan demikian sesuai ketentuan dalam Pasal 39 ayat 2 UUK maka upah pekerja atau buruh yang belum dibayar merupakan utang harta pailit sehingga harus didahulukan dikeluarkan dari harta pailit sebelum dibagi pada krediturkreditur lain. Berdasarkan penjelasan Pasal 39 UUK PKPU, upah merupakan hak pekerja yang diterima dan dinyatakan dalam bentuk uang sebagai imbalan dari pemberi kerja kepada pekerja atas suatu pekerjaan atau jasa yang telah dan akan dilakukan, ditetapkan dan dibayarkan menurut suatu perjanjian kerja, kesepakatan atau peraturan perundang undangan, termasuk tunjangan bagi pekerja dan keluarga. ${ }^{13}$ Dalam Pasal 1149 KUH Perdata pula telah menempatkan upah buruh sebagai kreditur preferen yaitu mempunyai hak istimewa atas benda bergerak dan tidak bergerak pada umumnya sehingga sebagaimana dimaksud Pasal 1131 KUH Perdata pelunasannya harus

12 Yani, Ahmad dan Widjaja, Gunawan, Seri Hukum Bisnis Kepailitan, Raja Grafindo Persada, Jakarta, 2002, hlm. 16

${ }^{13}$ Prinst Darwan, Hukum Ketenagakerjaan Indonesia, Buku Pegangan Bagi Pekerja untuk mempertahankan haknya, Cipta Aditya Bakti, Bandung. 2000, hlm. 47 
didahulukan. Penyelesaian utang upah buruh Debitur Pailit juga diatur dalam UU Ketenagakerjaan, Bab X tentang Perlindungan, Pengupahan dan kesejahteraan.

Ketentuan mengenai keistemewaan pembayaran upah buruh terdapat pada Pasal 95 Ayat 2 UU Nomor 13 Tahun 2003:

"Dalam Perusahaan dinyatakan pailit atau dilikuidasi berdasarkan peraturan perundang undangan yang berlaku, maka upah dan hak hak lainnya dari pekerja / buruh merupakan utang yang didahulkukan pembayarannya “.

Posisi buruh dalam memperjuangkan pembayaran upahnya merupakan hal yang beralasan dan kedudukan buruh merupakan posisi preferen karena:

a. Tagihan pembayaran upah pekerja adalah tagihan yang diistimewakan berdasar Pasal 1139 dan Pasal 1149 KUHPer;

b. Telah ada pengakuan Undang - Undang bahwa pembayaran upah menjadi utang harta pailit berdasar UUK Pasal 39 ayat 2;

c. Apabila terjadi perbedaan antara hitungan pekerja dengan daftar yang dikeluarkan oleh kurator, ada peran instansi pengadilan yang menangani, hal ini diatur dalam Pasal 127 ayat 1 UUK.

Pengaturan apakah upah buruh dapat mendahului kreditur separatis juga terdapat dalam Putusan Mahkamah Konstitusi No 18/PUU-VI/2008, atas permohonan pengujian Undang Undang Nomor 37 Tahun 2004 tentang Kepailitan dan Penundaan Kewajiban Pembayaran Utang terhadap UUD NRI Tahun 1945 yang diajukan oleh Federasi Ikatan Serikat Buruh Indonesia, yaitu mengenai kedudukan kreditur separatis yang dianggap melanggar hak asasi manusia yaitu hak buruh. Mahkamah Konstitusi berpendapat bahwa apakah kedudukan hukum utang buruh yang tidak secara tegas (expressis verbis) menyebut sebagai kreditur separatis maupun kreditur preferen dalam UUK, melainkan hanya dalam UU Ketenagakerjaan, hak-hak buruh harus dibayar terlebih dahulu.

Pemailitan BUMN oleh buruh sebagai sarana perlindungan hak buruh, dapat terlihat pada Putusan Pailit Pengadilan Niaga Jakarta Pusat dalam pengajuan permohonan pailit yang diajukan oleh mantan karyawan Berdasarkan syarat yang diamanatkan Undang-Undang tersebut, dalam kenyataan PT. Dirgantara Indonesia juga mempunyai dua/lebih kreditor yaitu mantan 
karyawan PT. Dirgantara Indonesia, utang yang dimaksud adalah kompensasi pensiun yang dituntutkan, dan utang tersebut telah jatuh waktu pelunasannya dan dapat ditagih. Putusan pailit tersebut mengundang banyak reaksi pro dan kontra. Kemudian menyikapi hal tersebut PT. Dirgantara Indonesia mengajukan Permohonan Kasasi ke Mahkamah Agung Republik Indonesia. Pengajuan Kasasi tersebut didasarkan pada ketentuan bahwa yang berwenang mengajukan permohonan pailit pada BUMN adalah Menteri Keuangan, dan karena PT. Dirgantara Indonesia merupakan BUMN maka Menteri Keuanganlah yang berwenang mengajukan Permohonan Pailit PT. Perusahaa yang dimaksud dengan BUMN pada UUK adalah BUMN yang bergerak di bidang Pelayanan Publik, yang jika dihubungkan dengan UU BUMN, BUMN yang dimaksud adalah Perum, sehingga untuk BUMN yang berbentuk Persero akan diberlakukan pula Ketentuan Undang-Undang Perseroan Terbatas selain juga Undang-Undang BUMN.

Debitor Pailit berhak membantah atas diterimanya suatu piutang baik seluruhnya maupun sebagian atau membantah adanya peringkat piutang dengan mengemukakan alasan secara sederhana untuk kemudian dicatat dalam berita acara rapat. Namun bantahan tersebut tidak menghalangi pengakuan piutang dalam kepailitan dan perlu diingat bahwa bantahan yang tidak menyebutkan alasan atau bantahan yang tidak ditujukan terhadap seluruh piutang tetapi tidak menyatakan dengan tegas bagian yang diakui atau bagian yang dibantah, tidak dianggap sebagai suatu bantahan. Apabila terdapat keberatan terhadap diajukannya piutang setelah lewat jangka waktu atau dalam hal timbulnya perselisihan mengenai ada atau tidak adanya halangan apabila Kreditor berdomisili di luar wilayah Negara Republik Indonesia, Hakim Pengawas wajib mengambil keputusan setelah meminta nasihat dari rapat.

\section{PENUTUP}

\section{Kesimpulan}

BUMN merupakan entitas perusahaan privat sehingga hukum yang mengatur tentang Ketenagakerjaan berlaku UU 13 Tahun 2003.Oleh karena UU tersebut berlaku bagi pekerja di BUMN, maka hak-hak normatif yang diatur dalam UU No 13 Tahun 2003 harus dipenuhi perusahaan untuk pekerjanya. Hak-hak normatif tersebut antara lain ketika perusahaan Pailit, yakni uang pesangon satu kali ketentuan Pasal 156 Ayat 2, uang pesangon masa kerja sebesar 
satu kali ketentuan Pasal 156 ayat 3 dan uang penggantian hak sesuai pasal 156 ayat 4 . Apabila ada hak-hak buruh yang tidak dipenuhi perusahaan BUMN, maka buruh dapat mengajukan pailit pada perusahaan tersebut, dalam kualifikasinya sebagai kreditur Preferen. Status BUMN harus dipaparkan secara jelas dalam suatu perusahaan, jika Negara ikut andil maka harus pula terdapat minimal 51\% saham didalamnya, sehingga fungsi pengendalian, pengaturan dan kontrolling yang dilakukan pemerintahpun jelas agar tujuan perusahaan tersebut tercapai, terutama untuk memproteksi komponen perusahaan apabila perusahaan tersebut pailit.

\section{Saran}

Agar tidak menimbulkan interpretasi yang berbeda adanya pengertian / makna yang sama mengenai BUMN yang bergerak dalam bidang kepentingan publik. Karena antara Pasal 2 ayat 5 UU No 37 Tahun 2004 dengan penjelasannya tidak sejalan. Pasal 2 ayat 5 UU Kepailitan menyebut tentang BUMN di bidang kepentingan publik, sementara pada penjelasan menyatakan BUMN yang seluruh modalnya dimiliki negara dan tidak terbagi atas saham. Antara isi pasal dan penjelasan tidak seinkron, maka seharusnya ketentuan tersebut menyebut langsung Perum, agar tercapainya kepastian hukum.

\section{DAFTAR BACAAN}

\section{Buku}

Abdul Hakim, Penghantar Hukum Ketenagakerjaan, Citra Aditya Bakti, Bandung, 2003;

Assers's, Pengajian Hukum Perdata Belanda Jilid III Hukum Perikatan, Dian Rakyat, jakarta, 2009;

Bahder Johan Nasution, Hukum Ketenagakerjaan Kebebasan Berserikat, Mandar Maju, Bandung, 2004;

F. Winarni dan G. Sugiyarso, Administrasi Gaji dan Upah, Pustaka Widyatama, Yogyakarta, 2006

H.M.N. Purwosuttjipto, Pengertian Pokok Hukum Dagang Indonesia 1: Pengertian Dasar Hukum Dagang, Djambatan, Jakarta, 1995; 
Kartini Muljadi, Prosiding Rangkaian Lokakarya Terbatas Masalah - Masalah Kepailitan Dari Wawasan Hukum Bisnis Lainnya, Pusat Pengkajian Hukum, Jakarta, 2005;

Munir Fuady, Perseroan Terbats Paradigma Baru, Citra Aditya Bakti, Jakarta, 2003;

: Hukum Pailit 1998, Dalam Teory dan Praktek, Citra Aditya Bakti, Bandung, 1999;

Sendjun W. Manullang, Pokok - Pokok Hukum Ketenagakerjaan di Indonesia, Rineka Cipta, Jakarta, 1998;

Rudhi Prasetya. Perseroan Terbatas Teori dan Praktik. Sinar Grafika, Jakarta, 2011;

Shubhan, M. Hadi, Hukum Kepailitan: Prinsip, Norma, dan Praktik di Pengadilan. Kencana.Surabaya, 2008;

Sutedi Adrian, Hukum Kepailitan, Ghalia Indonesia, Bogor, 2009;

Lalu Husni, Pengantar Hukum Ketenagakerjaan Indonesia, Ed. Revisi, Raja Grafindo Persada, Jakarta, 2006;

Prinst, Darwan, Hukum Ketenagakerjaan Indonesia, Buku Pegangan Bagi Pekerja untuk mempertahankan haknya, Cipta Aditya Bakti, Bandung. 2000;

Rudhy A. Lontoh, Denny Kailimang, dan Benny Ponto, [Eds.]., Penyelesaian Utang-Piutang: Melalui Pailit atau Penundaan Kewajiban Pembayaran Utang, Alumni, Bandung, 2001;

Soedarjadi, Hukum Ketenagakerjaan di Indonesia, Panduan bagi Pengusaha, Pekerja dan Calon Pekerja, Pustaka Yustisia, Jakarta, 2008;

Usman Rachmadi, Dimensi Hukum Kepailitan di Indonesia, Gramedia Pustaka Utama, Jakarta, 2004.

\section{$\underline{\text { Jurnal }}$}

Judicial Review No 18/PUU-VI/2008 Tentang Permohonan Uji Materil Undang Undang Nomor 37 Tahun 2004.

\section{Sumber Internet}

www.hukumonline.com/berita/baca/hol17859

www.kompas.com 